HStud 25 (2011)2, 203-213

DOI: 10.1556/HStud.25.2011.2.3

\title{
THE CHALLENGES OF RENEWED INDEPENDENCE: THE BALTIC STATES SINCE 1991
}

\author{
TOIVO U. RAUN \\ Indiana University \\ Bloomington, IN, USA
}

\begin{abstract}
This article offers a comparative assessment of how successfully Estonia, Latvia, and Lithuania have coped with the challenges of renewed independence since 1991, focusing on various aspects of political, economic, and social development. In the post-communist context the Baltic states have clearly outpaced other former Soviet republics and also performed reasonably well in comparison to the countries of Eastern Europe. The convergence of the Baltic experience, which began already in the early 20th century, has continued in the recent past as well, as the three states have adopted a number of similar approaches in domestic politics, the search for security, and economic policy. They also face a number of similar unsolved problems, including considerable political alienation, tensions in relations with Russia, socioeconomic disparity, and demographic challenges. The most important difference in the issues confronting the Baltic states today continues to be the large non-Baltic, mainly Russian presence in Estonia and Latvia, a result of Soviet-era policies. How to effect the meaningful integration of a multiethnic society remains a continuing challenge in these two countries. In contrast, population shifts under Soviet rule never became massive in Lithuania, and ethnic relations are a minor issue there today.
\end{abstract}

Keywords: Estonia, Latvia, Lithuania, ethnic relations, integration, Russians, independence, populism, neoliberal consensus, populations shifts

As they begin their third decade of renewed independence, the Baltic states of Estonia, Latvia, and Lithuania continue to occupy a liminal position as a borderland of the former Soviet Union, on the one hand, and the northernmost extremity of a broader, post-Cold War Eastern Europe, on the other. At the same time they are clearly also part of a new Baltic Sea region, including strong ties to the neighboring Scandinavian states, as well as members of the European Union since 2004, affirming that a growing range of identities and orientations is available to the Baltic peoples in the post-1991 world. The level of accomplishment attributed to the Baltic states in their political, economic, and social development in the past two decades depends to a large extent on the standard of measurement that is used. In comparison to the other former Soviet republics their successes clearly stand 
out in a number of areas. However, when their efforts are evaluated alongside those of the most developed countries of Eastern Europe, the picture is considerably more mixed. Beginning already with the Revolution of 1905 and then followed by the common experience of independence in the interwar years as well as the impact of nearly five decades of Soviet rule, the history of the Baltic states converged during the 20th century to the point where they were increasingly treated as a unit, especially by the outside world. This trend has continued since 1991, as seen, for example, in their simultaneous departure from the Soviet Union as well as their admission to both NATO and the European Union at the same time. Nevertheless, it is important to bear in mind that intra-Baltic diversity continues to exist, and as this article seeks to identify the commonalities in the Baltic experience in the past two decades, it will also pay attention to differences.

In contrast to the authoritarian regimes that emerged among their neighbors to the east, since 1991 the Baltic states have established smoothly functioning democratic systems in which the parliament reigns supreme alongside a figurehead president (Estonia and Latvia) or power is shared between the legislature and a directly elected president (Lithuania). During the period of renewed independence, six regularly scheduled parliamentary elections have been held in both Estonia and Latvia along with five in Lithuania. All have been declared fair and free by neutral observers and have proceeded without incident. In Estonia and Latvia there has been a welcome trend toward less volatility in elections for parliament, resulting in fewer and stronger parties obtaining representation. In both countries a breakthrough on the road to political stability recently occurred (2006 in Latvia, 2007 in Estonia), as incumbent prime ministers were returned to power for the first time following elections (Plakans, 2009, 521). On the eve of Andrus Ansip's unprecedented second straight electoral victory in March 2011, which would allow him to begin his seventh consecutive year as head of the Estonian government, pundits spoke of the country becoming more and more like "boring Scandinavia" (Masso, 2011).

Despite these apparent signs of political progress, however, critics suggest that in many ways they only represent the trappings of democracy, and a political culture in which citizens are strongly committed to democratic values still remains in the process of formation. The most persistent issue is a pervasive sense of political alienation among a considerable element of the Baltic populations. It is perhaps understandable that expectations would outpace results following the collapse of the Soviet system, but frustration with the performance of the political elites in each country has grown with the passage of time. Turnout for parliamentary elections declined already in the second half of the 1990s and fell to as low as 46 percent in Lithuania in 2004 before rising to 49 percent in 2008. In Estonia (2007, 2011) and Latvia $(2006,2010)$ the average turnout in the last two parliamentary elections was higher -62 percent in each case, but still lower than in the early 
years of independence. Opinion polls indicate that public trust in the parliaments and political parties in all three states has declined sharply since the beginning of independence in contrast to rather stable support for the presidents, who typically stand above the political fray; the courts; the police; and the military (Ehin, 2007, 14). There is also a growing reaction against the perceived elitism of politicians, who seem to make major decisions behind closed doors, and an electoral system that favors candidates chosen by each political party's inner circle (Saarts, 2010, 5; Veidemann, 2011). With regard to corruption there is a notable difference among the Baltic states. According to Transparency International's Corruption Perceptions Index for 2010, Estonia ranked 26th, Lithuania 46th, and Latvia 59th in the world (Transparency International, 2011). Following the establishment of the Corruption Prevention and Combating Bureau in Latvia in 2003, some progress was made despite resistance from various established politicians (Pridham, 2009, 474-5). Nevertheless, the issue of corruption has remained a central feature of Latvian politics, as seen most recently in President Valters Zatlers's confrontation with the country's parliament in summer 2011 over how far to proceed in investigating the activities of certain powerful political figures.

In Estonia and Latvia a continuing major challenge is how to integrate individuals who are not members of the titular nationality, i. e., ethnic Russians and others, into political life in a meaningful way. Largely because of Russian and other East Slavic out-migration, the Estonian (68.8 percent in 2010, up from 61.5 percent in 1989) and Latvian (59.4 percent in 2010, up from 52.0 percent in 1989) majorities have increased considerably in the past two decades, but ethnic Russians still comprise over a quarter of the population in each case (Statistikaamet, 2011; LR Centrāla statistikas pārvalde, 2011). The great majority of the rest of the population are also Russian speakers. By means of naturalization since the early years of independence a little more than half of the ethnic minorities in each country have acquired Estonian or Latvian citizenship. Nevertheless, because of troubled historical memories from Soviet times and a lack of trust among the major nationalities, the participation of ethnic Russians and Russian speakers in political life has remained limited. In Estonia no Russian-based political party has had any notable electoral success, and less than 10 percent of any parliament has consisted of non-Estonians. In Latvia, with its larger non-Latvian population, Russian-dominated parties have fared better, e. g., 29 percent of the seats in parliament for the Harmony Center in 2010, but no such party has ever participated in a national governing coalition (Centrālā vēlěšanu komisija, 2011).

In Lithuania, on the other hand, because of the strong ethnic Lithuanian majority (83.1 percent in 2010, 79.6 percent in 1989), the nationalities question has continued to be of minor concern (Lietuvos Statistikos Departamentas, 2011). Here the main political problem in the past decade has been the electorate's vulnerability to demagogic populism. The most striking example involved Rolandas Paksas, 
who in the December 2002-January 2003 presidential elections managed to defeat the much older incumbent, Valdas Adamkus, with outlandish promises to those groups in society who had been left behind in the transition from communism. After a little more than a year Paksas was impeached for violating his oath of office and endangering national security through alleged connections to the Russian mafia. He was removed from office by the Lithuanian Constitutional Court in April 2004, and Adamkus won a special election for president in June with a small majority (53 percent) in the second round over the veteran Soviet-era politician Kazimiera Prunskiene, who had opposed the impeachment of Paksas (Clark and Verseckaite, 2005, 16-18, 20-1; Balockaite, 2009, 19). In an important sense the existing political system had worked and was able to right itself, but the Lithuanian body politic, highly fragmented along socioeconomic and urban-rural lines, remained susceptible to manipulation because of the incomplete integration of society. The lower socioeconomic groups, who have fared poorly in the transition to capitalism, continued to provide a base for populist appeals, e. g., Viktor Uspaskikh whose newly formed Labor Party became the largest group in the Lithuanian Seimas following parliamentary elections in October 2004 (Fritz, 2007, 253-4; Clark and Verseckaite, 22).

The search for security by the Baltic states in the past two decades provides a striking contrast to the situation during their first independence period in the 1920s and 1930s. In the interwar era Estonia, Latvia, and Lithuania were only able to cobble together a weak and toothless alliance among themselves as a last resort, the Baltic Entente of 1934. When confronted with crisis in 1939-40, they each chose to stand alone. Since 1991, on the other hand, the Baltic states have become fully integrated into the international state system, most importantly gaining admission to both NATO and the European Union in Spring 2004 as support for both hard and soft security. To be sure, skeptics in the Baltic states harbor some doubts about NATO's level of commitment to Baltic independence, but membership in the Euro-Atlantic alliance clearly serves as a deterrent to potential military action from the main successor to the Soviet Union. The key remaining puzzle for the foreign policies of the Baltic states is how to build a workable and constructive relationship with their large eastern neighbor, which has yet to fully accept Estonia, Latvia, and Lithuania as equal partners instead of occupants of "post-Soviet space" in which Russia should maintain a privileged sphere of influence (Raun, 2009, 532). Since 2004, Baltic-Russian relations have gradually improved, although periodic flare-ups have occurred, most notably the Bronze Solder affair in Estonia in April 2007 in which the Estonian government's decision to move a World War II monument led to a riot by Russian youth in Tallinn. The Russian Federation condemned the Estonian authorities, even calling for a change of government as a result of the event, and an extensive cyber attack from ostensibly unknown, but predictable sources was directed against official Estonian web sites. 
Nevertheless, there are clear indications that Russia increasingly recognizes Baltic integration with the West as a fact of life and that in a rapidly changing world the entire Baltic question has become less and less of a priority in Russian foreign policy (Asjatundja, 2010).

Despite the recent recession the economy has been a major Baltic success story, although the level of achievement certainly varied among the three countries. With Estonia leading the way all three states quickly adopted a policy of free-market liberalism - a Baltic form of "shock therapy" - along with a separate currency in order to escape from the post-Soviet economic orbit and the rampant inflation of the ruble zone as soon as possible. In view of the enormous contrast to Soviet policies, this approach was ideologically attractive to many Baltic reformers, and it also fit well with the views of the main international institutions providing advice on the economic transition, e. g., the World Bank and the International Monetary Fund (Lauristin and Vihalemm, 2009, 8-10; Steen, 2007, 90). Because of its early success and continuing edge over its Baltic neighbors, Estonia has often served as a model for the other two, including, for example, the adoption of a flat income tax, and the past two decades have witnessed a convergence in Baltic economic policies (Fritz, 2007, 277). Why Estonia in particular has played this leading role remains a subject of debate. The northernmost Baltic republic had the widest opening to the outside world via Finland during the Soviet era - including access to Finnish television, radio, and large numbers of foreign visitors - helping to keep Estonia in better touch with developments in the international economy. Cultural arguments based on the long-term impact of the strong Pietist tradition in Estonia, especially the influence of the Moravian Brethern, have also been offered (Norkus, 2007, 25).

All three Baltic states achieved excellent GDP growth rates from the late 1990s through 2007 (sometimes reaching double digits) with the average annual rate reaching 8.6 percent in Latvia, 8.2 percent in Estonia, and 7.5 percent in Lithuania in the years 2000-07 (Hübner, 2011, 82). Nevertheless, in seeking to catch up to Western levels of economic development, Estonia led the way with the biggest jump in GDP per capita among post-communist members of the European Union from 1995 to 2007 - from 36 to 69 percent of the EU average, although Lithuania ( 36 to 59 percent) and Latvia (31 to 56 percent) were not far behind (GDP per capita in PPS, 2011). Well before achieving EU membership, the three countries also made membership in the euro zone a top priority. To date, only Estonia, which adopted the euro in January 2011, has met the stringent Maastricht criteria, as the recent recession finally brought inflation under control. The crisis of the last few years, which hit the overheated Baltic economies especially hard and led to drastic, if temporary, declines in GDP and soaring unemployment, was a sobering experience. Nevertheless, it is striking that the commitment to free-market and consumerist values among Baltic political leaders and much of the population ap- 
pears to be unshaken. For the future, the economic challenge will be to find new and effective ways to achieve success in the increasingly globalized and competitive marketplace (Saarts, 2010, 5; Lauristin and Vihalemm, 2009, 16).

As already noted, in Estonia and Latvia the most difficult and intractable legacy of the Soviet era is the presence of a large non-Baltic - overwhelmingly Russian and other East Slavic - population, the result of both forced and voluntary migration under Stalin and his successors. Beyond the issue of political participation treated above, there remains the more general concern about how the still disparate majority and minority communities can move toward a more fully integrated society. Importantly, in view of the numerous instances of violent conflict among nationalities in post-communist societies, ethnic relations in the Baltic states have remained almost entirely non-violent, both in the turbulent waning days of Soviet power and since 1991. In the Estonian case peaceful relations are often attributed to a tendency to segregate by nationality with Russians concentrated in the nearly non-Estonian northeast and the large urban complex of Tallinn (Heidmets, 1998, 264-73). In Latvia Russians and other non-Latvians are strongly present in all the major cities and in the region of Latgale in the southeast. In contrast to Estonia where the number of ethnically mixed marriages remains low, intermarriage rates in Latvia have historically been high and continue to be so, including among ethnic Latvians and Russians. In the years 2000-08, for example, about 20 percent of Latvians married outside their ethnicity and 40-45 percent of Russians did so (Plakans, 2009, 523; Latvijas statistikas gadagrāmata, 2010, 139, 143). Thus, social integration at the personal level is more in evidence in Latvia and may play an increasingly important role in the future.

Following an initial period when it was hoped that large-scale emigration would resolve the minority issue, the governments of Estonia and Latvia began to accept responsibility for ethnic integration in the second half of the 1990s. They were strongly encouraged along these lines by international organizations such as the European Union, which the Baltic states sought to join at this time, and the Organization for Security and Cooperation in Europe. The stated goal in both countries became a multicultural society in which all ethnic groups would retain their native languages and cultures, but the language of the titular nationality would serve as the basis for uniting all residents around a common civic identity. Citizenship requirements were liberalized in the late 1990s, and the proportion of stateless persons and non-citizens has gradually, but continually declined since then. Nevertheless, it is clear that any process of meaningful integration remains incomplete. A continuing legacy of the Soviet era, when the Russian language held a privileged position in the non-Russian republics, is asymmetrical bilingualism; i.e., knowledge of Russian is still more widespread than that of Latvian or Estonian. In 1989, only 22 percent of ethnic Russians living in Latvia could speak Latvian while fully 68 percent of Latvians had a command of Russian. By 2000, 
the proportion of Russians able to speak Latvian had risen to 53 percent, but the overall disparity in favor of Russian has continued to the present day (Raun, 1994, 166; Muižnieks, 2006, 20). In Estonia a comparable situation prevails. A distinctly positive sign in both countries is the much stronger command of the titular languages by younger generations of Russians and other non-Balts, and this trend augurs well for the future. On the other hand, it should also be noted that ability to speak a language does not necessarily equate with any substantial integration. Despite the improving command of the Estonian language among non-Estonians in Estonia, the Bronze Soldier affair demonstrated the fragility of integration among a large proportion of local Russians who felt they were treated as second-class citizens according to surveys taken after the riots (Vihalemm and Kalmus, 2009, 95).

As a long-term solution to the challenge of integration, the educational system was often viewed as holding great promise for promoting closer ties among nationalities. However, both Latvia and Estonia inherited the prevailing Soviet system of schools that were segregated by language of instruction. In the Soviet period Latvian, Estonian, and Russian parents generally welcomed this approach as a means to assure full command of the native language. Because of the privileged and prestigious status of the Russian language in the Soviet Union, in practice ethnic Baltic pupils learned Russian very well, but Russian pupils typically acquired little or even no command of Estonian or Latvian. In the past two decades reformers in the two countries have upgraded instruction in the majority language and successfully introduced various forms of bilingual education in Russian-language elementary schools. The major bone of contention has been how and to what extent bilingual education should be implemented in state-supported secondary schools. After much heated debate Latvia established a program in September 2004 whereby 60 percent of the instruction would be conducted in Latvian and 40 percent in Russian. Satisfaction with the reform tends to be divided along ethnic lines with Latvians generally in favor and Russians opposed (Schmid, 2008, 11, 14). In Estonia a similar reform has been postponed several times and is now due to be implemented in September 2011, although nearly half the Russian secondary schools in Tallinn claim neither their teachers nor students are ready for the change (Ligi pool Tallinna vene gümnaasiumitest, 2011). Beyond the language issue there remains the matter of standardizing the content of what is taught. A recent study of minority education in Estonia and Latvia finds that teachers in minority schools often follow a "hidden curriculum" in order to "correct" the state-mandated approach (Golubeva, 2010, 327).

In stark contrast, ethnic relations in Lithuania appear to be increasingly benign, in large part because of the small size of the minority population and its continual decline. It is noteworthy that already in 1989 Lithuanian-Russian bilingualism was equal; that is, 38 percent of each nationality could speak the other's language. In the past two decades the ethnic Russian presence has been reduced to only 4.8 
percent in 2010 compared to 9.4 percent in 1989 , and the Polish minority has also fallen to 6.0 percent (versus 7.0 percent in 1989) (Raun, 1994, 166; Lietuvos Statistikos Departamentas, 2011). In this situation it is perhaps not surprising that the ethnic Russians and Russian speakers who have remained in Lithuania identify strongly with that country and much less with Russia. In a survey taken in 2004, fully 75 percent of the Russian speakers polled indicated a primary or secondary identification with Lithuania, but only 14 percent chose such an association with Russia. In the same survey, which included residents in all three Baltic states, Russian speakers in Estonia and Latvia overwhelmingly identified with the Russian Federation and only to a small degree with their country of residence. In Estonia, 72 percent of the Russian speakers noted a primary or secondary identification connected to Russia, but only 3 percent said the same with regard to Estonia. In Latvia, the corresponding figures for Russian speakers were 61 percent identifying with Russia and 13 percent identifying with Latvia (Ehin, 2007, 9).

As we have seen, the dominant ideology articulated by Baltic governments in the post-communist era has rejected the Soviet past and emphasized individual economic achievement and materialist values. This was the case even in Lithuania where the ex-communists were able to transform themselves into a strong social democratic party. Those social groups who successfully negotiated the transition to free-market capitalism have accepted a 'neoliberal consensus' (Fritz, 2007, 255; Saarts, 2010, 5). Outside observers and international organizations typically give the Baltic states high marks for their performance on a global scale. The United Nations Human Development Index for 2010 rated Estonia 34th, Lithuania 44th, and Latvia 48th out of a total of 169 countries in the world (United Nations Human Development Index, 2011). Nevertheless, not everyone in the Baltic societies has benefitted or is satisfied with the results. During the past decade all three Baltic states have had some of the highest levels of income disparity among EU member states, as measured by the Gini index. Compared to several other post-communist states, including Slovenia, the Czech Republic, Slovakia, and Hungary, the Baltic countries do poorly, and poverty levels are high. Expenditure on health care in Estonia, Latvia, and Lithuania has lagged behind that in other East European EU member states (Gini Coefficient, 2011; Adam, Kristan, and Tomšič, 2009, 76). Already in 2001, Estonian social scientists warned of the division of society into 'two Estonias', separated by an increasing gap in wealth. To date, because of the strength of the neoliberal consensus, no Baltic government has felt the need to attack this problem head on, and the recent recession has reduced state funding for services even further. Instead they have opted for calculated strategic moves such as the Estonian Reform Party's modest increase in support to pensioners and mothers, a step that has paid off in recent elections and helped to broaden its political base (Saarts, 2010, 5). 
As has been the case in the rest of post-communist Eastern Europe, the Baltic states have witnessed significant population losses in the past two decades. The extent of the decline is such that the situation can be termed critical, especially in view of the bleak prospects for substantially reversing recent demographic trends. Following the collapse of the Soviet Union, birth rates plummeted and death rates rose markedly, and as noted above, massive non-Baltic emigration took place in the first half of the 1990s, continuing at a slower pace after that. In contrast to the situation in the Soviet period, Lithuania now followed the same demographic pattern as Estonia and Latvia. Estonia's total fertility rate bottomed out at 1.28 in 1998, but Lithuania's fell even lower to 1.23 in 2002 (Eesti statistika aastaraamat, 2007, 47; Lietuvos statistikos metraštis, 2009, 49). Out-migration in search of employment by Estonians, Latvians, and Lithuanians also increased, especially after EU membership in 2004, and many Baltic university students took advantage of new opportunities to obtain degrees abroad. How permanent this economic and academic migration would continue remains to be seen. Hopes for the future were raised by the slowing down of the negative natural increase in all three Baltic states in recent years, and in Estonia, where birth and death rates are currently more or less in balance, various politicians claimed credit for a demographic 'miracle' based on increased parental support by the government. However, analysts point out that the more important factors are the current, but temporary presence of a relatively large generation of potential mothers (born before 1990 and the precipitous decline in birth rates) and improvements in the quality of life during the last decade (Uudelepp, 2011, 3; Teadlane, 2011). Within ten years or so much smaller cohorts of child-bearing women will be available, and the long-term prospects for demographic stability or growth remain distinctly unfavorable. Other than some welcome provisions for parental leave from employment, Baltic political leaders have come up short in offering solutions to this challenging problem.

Overall, in seeking to meet the challenges of renewed independence the Baltic states have achieved a number of successes that compare favorably with the performance of other post-communist countries, most notably those that were formerly part of the Soviet Union, but also those located in the Eastern Europe of the Cold War era. With certain variations Estonia, Latvia, and Lithuania have adopted a number of common approaches in domestic politics, the search for security as independent states, and economic policy. The unsolved problems facing them are also highly similar, including overcoming political alienation, establishing stable and functional relations with Russia, combating increasing socioeconomic disparity, and coping with population issues that border on a demographic crisis. In comparison, the divergences in their experience, such as Estonia's greater macroeconomic success, are relatively minor. The one major disparity, the issue of eth- 
nic integration in Latvia and Estonia, is the most significant legacy of the distortions created during the Soviet era, and even here the two countries involved have increasingly offered similar solutions to this challenge. In short, there are numerous indications that the gradual convergence of modern Baltic history, which began in earnest over a century ago, has continued to develop in the past two decades and is likely to do so in the foreseeable future as well. Nevertheless, an irreducible level of diversity, based on such factors as language, religious tradition, customs, and the legacy of historical experience in the longue durée, will endure as well.

\section{Works cited}

Adam, Frane; Kristan, Primož; and Tomšič, Marvež (2009) 'Varieties of Capitalism in Eastern Europe (with Special Emphasis on Estonia and Slovenia)' Communist and Post-Communist Studies, Vol. 42, No. 1, 65-81.

‘Asjatundja: Venemaa ei suurenda poliitilist kohalolekut Eestis' (Expert: Russia Will Not Increase Its Political Presence in Estonia)' (2010) Postimees, 16 August. Available at: http://www.postimees.ee (accessed 16 August 2010).

Balockaite, Rasa (2009) 'Can You Hear Us? The Lower Class in Lithuania Media and Politics' Problems of Post-Communism, Vol. 56, No. 1, 12-22.

Centrālā vēlēšanu komisija (Central Electoral Commission of Latvia). Available at: http://web.cvk.lv (accessed 30 June 2011).

Clark, Terry D. and Verseckaite, Egle (2005) 'PaksasGate: Lithuania Impeaches a President' Problems of Post-Communism, Vol. 52, No. 3, 16-24.

Eesti statistika aastaraamat 2007 (Statistical Yearbook of Estonia 2007) (2007) (Tallinn: Statistikaamet).

Ehin, Piret (2007) 'Political Support in the Baltic States, 1993-2004' Journal of Baltic Studies, Vol. 38, No. 1, 1-20.

Fritz, Verena (2007) State-Building: A Comparative Study of Ukraine, Lithuania, Belarus, and Russia (Budapest: Central European University Press).

GDP per capita in PPS. Available at: http://epp.eurostat.ec.europa.eu (accessed 12 March 2011).

Gini Coefficient. Available at: http://epp.eurostat.ec.europa.eu (accessed 12 March 2011).

Golubeva, Maria (2010) 'Different History, Different Citizenship? Competing Narratives and Diverging Civil Enculturation in Majority and Minority Schools in Estonia and Latvia' Journal of Baltic Studies, Vol. 41, No. 3, 315-29.

Heidmets, Mati (1998) 'The Russian Minority: Dilemmas for Estonia' Trames, Vol. 2, No. 3, 263-73.

Hübner, Kurt (2011) 'Baltic Tigers: The Limits of Unfettered Liberalization' Journal of Baltic Studies, Vol. 42, No. 1, 81-90.

Latvijas statistikas gadagrāmata 2009 (Latvian Statistical Yearbook 2009) (2010) (Riga: Latvijas Republikas Centrālā statistikas pārvalde).

Lauristin, Marju and Vihalemm, Peeter (2009) 'The Political Agenda During Different Periods of Estonian Transformation: External and Internal Factors' Journal of Baltic Studies, Vol. 40, No. $1,1-28$.

Lietuvos Statistikos Departamentas (Statistics Lithuania). Available at: http://stat.gov.lt (accessed 29 June 2011). 
Lietuvos statistikos metraštis 2009 (Statistical Yearbook of Lithuania 2009) (2009) (Vilnius: Statistikos Departamentas).

'Ligi pool Tallinna vene gümnaasiumitest pole eestikeelseks õppeks valmis' (Nearly One Half of the Tallinn Russian High Schools Are Not Ready for Instruction in Estonian) (2011) Postimees, 18 March. Available at: http://www.tallinnapostimees.ee (accessed 19 March 2011).

LR Centrālā statistikas pārvalde (Central Statistical Bureau of the Republic of Latvia). Available at: http://www.csb.gov.lv (accessed 30 June 2011).

Masso, Iivi Anna (2011) 'Igavad valimised' (Boring Elections). Postimees, 28 February. Available at: http://www.postimees.ee (accessed 2 March 2011).

Muižnieks, Nils (2006) 'Government Policy and the Russian Minority' in Nils Muižnieks (ed.) Latvian-Russian Relations: Domestic and International Dimensions (Riga: LU Akademiskais Apgāds) 11-21.

Norkus, Zenon (2007) 'Why Did Estonia Perform the Best? The North-South Gap in the Post-Socialist Economic Transition of the Baltic States' Journal of Baltic Studies, Vol. 38, No. 1, $21-42$.

Plakans, Andrejs (2009) 'Latvia: Normality and Disappointment' East European Politics and Societies, Vol. 23, No. 4, 518-25.

Pridham, Geoffrey (2009) 'Post-Soviet Latvia - A Consolidated or Defective Democracy? The Interaction Between Domestic and European Trajectories' Journal of Baltic Studies, Vol. 40, No. 4, 465-94.

Raun, Toivo U. (1994) 'Ethnic Relations and Conflict in the Baltic States' in W. Raymond Duncan and G. Paul Holman, Jr. (eds) Ethnic Nationalism and Regional Conflict: The Former Soviet Union and Yugoslavia (Boulder, CO: Westview), 155-82.

Raun, Toivo U. (2009) 'Estonia After 1991: Identity and Integration' East European Politics and Societies, Vol. 23, No. 4, 526-34.

Saarts, Tõnis (2010) 'Rahvusliberalism - ideoloogia keskmisele eestlasele' (National Liberalism An Ideology for the Average Estonian) Sirp, 26 November, 5.

Schmid, Carol (2008) 'Ethnicity and Language Tensions in Latvia' Language Policy, Vol. 7, No. 1, 3-19.

Statistikaamet (Statistics Estonia). Available at: http://www.stat.ee (accessed 29 June 2011).

Steen, Anton (2007) 'Do Elite Beliefs Matter? Elites and Economic Reforms in the Baltic States and Russia' in Fredrik Engelstad and Trygve Gulbrandsen (eds) Comparative Studies of Social and Political Elites (Amsterdam: Elsevier), 79-102.

'Teadlane: iive võib jääda kümneks aastaks nulli lähedale ja siis tuleb langus' (Scholar: Population Growth May Remain Near Zero for Ten Years and Then Decline) (2011) Eesti Päevaleht, 1 March. Available at: http://www.epl.ee (accessed 1 March 2011).

Transparency International. Available at: http://www.transparency.org (accessed 29 June 2011).

United Nations Human Development Index. Available at: http://hdr.undp.org (accessed 29 June 2011).

Uudelepp, Ago (2011) ‘Padaemand valimistel' (The Queen of Spades in the Elections) Sirp, 28 January, 3.

Veidemann, Rein (2011) 'Isetäituv riigikogu' (Self-Filling Riigikogu) Postimees, 3 February. Available at: http://politiika.postimees.ee (accessed 6 February 2011).

Vihalemm, Triin and Kalmus, Veronika (2009) 'Cultural Differentiation of the Russian Minority' Journal of Baltic Studies, Vol. 40, No. 1, 95-119. 